УДК 339.5:631.1

\author{
Iryna Skorokhod, \\ PhD in Economics, Associate Professor, \\ Lesya Ukrainka Eastern European National University, \\ Department of International Economic Relations and Project Management, \\ Luts, ORCID ID: 0000-0001-8628-3715 \\ e-mail: skorokhodiryna1@gmail.com
}

\author{
Nataliia Hrytsiuk, \\ Student of Master Specialty of Faculty of International Relations, \\ Lesya Ukrainka Eastern European National University, Lutsk \\ e-mail: hrytsiuknat@gmail.com
} https://doi.org/10.29038/2411-4014-2020-03-44-50

\title{
ORGANIC PRODUCTION EXPORTS CREDITING IN UKRAINE
}

The main aspects of the organic production export crediting are investigated in this article. As export crediting today is an extremely relevant and important issue in Ukraine, there is a wide base of research in this area. However, despite the number of developments, today there is no established mechanism for the organic production export crediting. Nowadays, the export of organic production in Ukraine is actively evolving, so it needs additional financial support for growth. One of the tools to support the export of organic products is lending. Therefore, the purpose of the study is to analyze the theoretical foundations and practical aspects of lending for organic exports. The current state of the export of organic products in Ukraine has been studied. The regional distribution of organic production export is determined. The main ways of export crediting are also investigated. The existing experience of crediting the export of organic production in Ukraine and the world is analyzed. In particular, one of the main tools for organic product export crediting has been identified. The problems faced by the producer of Ukrainian organic products are identified and ways to solve them are suggested. Prospects for the development of organic product export crediting in Ukraine are considered. Thus, the study presents recommendations that can be immediately used for practical implementation as a tool for organic product export crediting.

Keywords: organic production, export credit, export credit agency, financial support of export, export programs.

Скороход Ирина,

кандидат экономических наук, доцент,

Восточноевропейский национальный университет имени Леси Украинки, кафедра международных экономических отношений и управления проектами, г. Луцк

Грицюк Наталия, студентка магистратуры факультету международных отношений Восточноевропейского национального университету имени Леси Украинки, г. Луцк

\section{КРЕДИТОВАНИЯ ЭКСПОРТА ОРГАНИЧЕСКОГО ПРОИЗВОДСТВА В УКРАИНЕ}

В статье рассмотрены особенности кредитования экспорта органического производства в Украине. Органическое производство в стране активно развивается. Одним из инструментов поддержки экспорта продукции органического производства является кредитование. Поэтому целью исследования определены изучение теоретических основ и практических аспектов кредитования экспорта органического производства. Исследовано современное состояние экспорта продукции органического производства в Украине. Определены региональное распределение экспорта органического производство. Проанализирован опыт кредитования экспорта органического производства в Украине и мире. Определены проблемы, с которыми сталкивается производитель украинской органической продукции и предложены пути их решения. Рассмотрены перспективы развития кредитования экспорта продукции органического производства в Украине. 
Ключевые слова: органическое производство, кредитование экспорта, экспортно-кредитное агентство, финансовая поддержка экспорта, экспортные программы.

\section{Скороход Ірина, \\ кандидат економічних наук, доцент,}

Східносвропейський національний університет імені Лесі Українки, кафедра міжнародних економічних відносин та управління проектами,

м. Луцьк

Грицюк Наталія,

студентка магістратури факультету міжнародних відносин Східносвропейського національного університету імені Лесі Українки, м. Луцьк

\section{КРЕДИТУВАННЯ ЕКСПОРТУ ОРГАНІЧНОГО ВИРОБНИЦТВА В УКРАЇНІ}

В наш час галузь органічного виробництва відіграє важливу роль не лише в економіці України, але й в світі загалом. Прослідковується постійне збільшення попиту на органічну продукцію в країнах Європейського Союзу, Канади та Китаю. Завдяки географічному положенню та наявністю всіх необхідних ресурсів Україна $\epsilon$ конкурентоспроможною та може займати важливе місце в цій галузі. Проте, щоб досягнути необхідних обсягів виробництва органічної продукції, необхідно застосовувати потужні інструменти кредитування експорту.

Метою статті є дослідження особливостей кредитування експорту органічного виробництва в Україні та визначення шляхів вдосконалення механізму експортного кредитування органічної продукції.

Акцентується увага на основних аспектах кредитування експорту органічного виробництва. Оскільки кредитування експорту в Україні сьогодні є надзвичайно актуальним та важливим питанням, існує широка база досліджень цієї сфери. Проте, не зважаючи на кількість напрацювань, сьогодні немає налагодженого механізму кредитування експорту органічного виробництва. Експорт органічного виробництва в Україні активно розвивається, тому потребує додаткової фінансової підтримки для росту. Одним з інструментів підтримки експортування продукції органічного виробництва є кредитування.

Досліджено сучасний стан експорту продукції органічного виробництва в Україні. Визначено регіональний розподіл експорту органічного виробництва. Також досліджено основні шляхи кредитування експорту. Проаналізовано наявний досвід кредитування експорту органічного виробництва в Україна та світі. Зокрема, визначено один з основних інструментів кредитування експорту органічної продукції. Визначено проблеми, з якими стикається виробник української органічної продукції та запропоновані шляхи їх розв'язання. Розглянуто перспективи розвитку кредитування експорту продукції органічного виробництва в Україні. Таким чином дослідження представляє рекомендаційні розробки, які можна використати для практичного втілення у ролі інструменту кредитування експорту органічної продукції.

Ключові слова: органічне виробництво, кредитування експорту, експортно-кредитне агентство, фінансова підтримка експорту, експортні програми.

Formulation of the problem. The organic agricultural sector in Ukraine has been growing steadily since the early 2000s. However, there is considerable scope for further growth in this sector, not least due to its geographical proximity to the solvent and growing organic markets of the European Union (EU). Demand for organic products in the agricultural sector in some countries far exceeds supply, which is profitable and promising for organic enterprises. That is why the study of organic production export crediting in Ukraine is appropriate and relevant.

The analysis of researches and publications. The study of organic production, features, and prospects of its development in Ukraine is given much attention by scientists such as V. Artish, V. Granovska, O. Dudar, M. Kobets, O. Kuzmenko, E. Mylovanov, O. Khodakivska, T. Borovik, Zh. Deriy, M. Kropivko, T. Mostenska, P. Skripchuk, G. Tarasiuk, T. Chaika, V. Chudkovska, V. Shcherban, V. Shlapak, and others. Despite the importance of scientific work, the scientific substantiation of the organic production export crediting essence remains relevant.

The purpose of the article is to study the features of the organic production export crediting in Ukraine, the development of appropriate scientific and practical recommendations for improving the 
mechanism of the organic production export crediting. Achieving this has led to the study of the methodological foundations of export credit for organic production and the systematization and characteristics of types of organic production export crediting.

Despite the relatively deep process of studying the very sphere of organic production, the issue of the organic production export crediting in modern scientific literature is insufficiently considered. That is why these issues need further comprehensive research. The purpose of the article is also to define the concept of the organic production export crediting, the factors of its formation, justification of the need to increase crediting of the organic industry and analysis of existing theoretical research.

Presentation of the main research material. The world market for organic products began to develop at the end of the last century. In Ukraine, the production of organic products is undergoing a period of formation, and a significant positive shift, which makes it possible to activate the market of organic products, is the adoption of the Law of Ukraine "On production and circulation of organic agricultural products and raw materials."[1] It should be noted that the development of organic agriculture is a topical and at the same time controversial issue for the functioning of agricultural enterprises under competitive conditions. Organic farming as a holistic management system combines best practices in terms of environmental protection, biodiversity, conservation of natural resources, application of high standards of proper animal husbandry and production methods that meet certain requirements for products made using substances and processes of natural origin. In the scientific community, there are many interpretations of the concept of "organic farming". Considering the position of E. Milovanov, we may see that he defines organic agriculture as an agricultural system that contributes to the preservation of the environment, socially and economically supports the production of healthy food. This type of farming avoids the use of chemically synthesized fertilizers, pesticides, veterinary drugs, while actively using natural products to increase the natural fertility of soils, the resistance of plants and animals to disease [2]. As noted by O. Khodakivska, the first certified farms were created on the initiative of foreign companies, which covered the costs associated with land certification and exported the products grown abroad in the form of raw materials. With the direct support of foreign organizations, the main "players" in the market of domestic organic products have been created [3]. Y. Lupenko in his study notes that the formation of the market for organic products in Ukraine is influenced by internal and external factors. Internal factors cause an increase in demand for safe and healthy food with increasing living standards. External factors are caused by the dynamic growth of the world market of organic products and the interest of the international community in Ukraine as a potentially powerful producer of such products. Given the world experience of Y. Lupenko identifies 4 stages of the formation and development of the market of organic products (Table 1) [4].

Development of the organic products market

\begin{tabular}{|l|l|}
\hline Stage & \multicolumn{1}{|c|}{ Characteristic } \\
\hline Sectoral & $\begin{array}{l}\text { Farmers and consumers interested in consuming } \\
\text { healthy food are organized into clubs, societies, } \\
\text { organizations. }\end{array}$ \\
\hline Market & $\begin{array}{l}\text { The number of organic products producers is } \\
\text { growing, associations and professional groups are } \\
\text { being formed, and the legal framework for the } \\
\text { activities of organic production entities is being } \\
\text { created. }\end{array}$ \\
\hline Nationwide & $\begin{array}{l}\text { Laws are being created, the infrastructure of } \\
\text { production, processing and sale of organic products } \\
\text { is being developed. }\end{array}$ \\
\hline Source: 4$]$ & $\begin{array}{l}\text { Society is aware of the benefits and advantages of } \\
\text { organic production; the state actively helps to } \\
\text { develop both supply and demand for organic food. }\end{array}$ \\
\hline
\end{tabular}

Source: [4]

As noted by Y. Lupenko, Ukraine is in the third stage of the formation of the organic product's entry market. The transition to the national stage of development is associated with public awareness of 
environmental issues [4]. The infrastructure of the organic market today is underdeveloped, so producers are severely limited in the application of marketing approaches to the promotion of goods. The lack of a legal framework and an appropriate certification system also creates many difficulties for producers, in particular regarding the positioning of products on the market. Given that most organic products are sold for export, the saturation of the domestic market is insufficient.

The modern development of agriculture in the European Union and the United States is characterized by a steady increase in the area used for organic production of agricultural products. However, there is a shortage of organic products in developed countries.

It should be noted that the growth of organic production in Ukraine is primarily due to the increase in its consumption in Europe. As a result of the study, it was found that in the countries of the European Union the niche of organic raw materials is not filled. Europe consumes more eco-products than it produces. Moreover, every year consumption increases by $10 \%$. Therefore, the prospects for the development of the domestic market are great. In addition, EU countries are making significant efforts to reduce supplies from China and increase them from neighboring countries, including Ukraine.

Ukrainian organic products are exported mainly to EU countries. According to the Ministry of Agrarian Policy, the export items are cereals and oilseeds, berries, blueberries, birch sap, pumpkin seeds, mustard, apple concentrate. We can conclude that the domestic market for organic products is still underdeveloped, but export-oriented. Exports of organic products are currently mainly carried out through certified foreign trade companies that have sufficient practical experience, knowledge of specialized markets for organic products and regularly monitor the latest trends in this area. Ukrainian agricultural enterprises have real competitive advantages in the market of organic and environmentally friendly products in Europe. Also promising for the expansion of markets is the Chinese market, which generates effective demand for clean, environmentally friendly, and organic products. The existing imbalance between supply and demand in the EU markets, the dynamic development of national organic production contributes to the promotion of Ukrainian agricultural products on the world market.

State support for the export of organic products is becoming an urgent need. In world practice, there are a large number of mechanisms to support the export of administrative (duties, quotas, etc.) and economic content (subsidies, consultations, products of specialized institutions). In particular, measures of economic content are based on the provision of services by specialized institutions, which have a generalized name of export credit agencies. Their role is also performed by export-import banks and specialized insurance companies. Ukraine, as a member of the WTO, must apply in its activities the mechanisms and procedures officially recognized by this organization.

One of the effective mechanisms is state support for exports through insurance and crediting. The adoption of a bill on state incentives for high value-added products could be a tangible step towards optimizing the financing of domestic producers and processors of agricultural products. It is important to develop a bill to ensure the large-scale export expansion of Ukrainian producers by insuring, guaranteeing, and reducing the cost of export crediting. It should be aimed at introducing state support for exports through the creation of a specialized state institution, which through the insurance mechanism should stimulate an increase in exports, improve the trade balance and promote economic development in general. This bill envisages determining the legal preconditions for the introduction of one of the mechanisms of state export support in Ukraine - the creation of a state institution that will insure (reinsure) risks and guarantee operations under foreign trade agreements of exporters, as well as cheaper export credits, which will indirectly stimulate agricultural development. In fact, the bill provides for the establishment of an insurance institution that should be a partner of exporters and provide insurance and guarantee services in risky areas. Such support will primarily concern the provision of manufacturing products and, in general, products with a higher share of value added. This effective tool has been used effectively by exporters for decades to minimize their own costs and risks, which promotes business development and indirectly the development of the internal market. In almost 70 years of existence, the US Export-Import Bank has stimulated American exports worth more than 400 billion US dollars. The total amount of loans granted in 2012 only by the KfW banking group to support German exports amounted to 13.4 billion euros.

Implementation of state policy in the field of organic production in the region and implementation of the main tasks of the Program should be carried out in areas that will improve the economic performance of economic entities in the agricultural sector of the region, increase their contribution to employment and 
filling budgets, creating new jobs, improving the environmental situation in the region. The main directions of the Program are regulation of normative regulation of organic production development, financial and credit, and investment support, information support, the formation of the infrastructure of organic production development, conducting research, and advanced training of personnel for the sphere of organic production.

Financial, credit, and investment support provides for the simplification of access of economic entities in the field of organic production to credit and investment resources, providing favorable conditions for their development, creating new jobs. Direct financial support of economic entities in the field of organic production should be provided on the terms of joint financing from the state, regional and local budgets, as well as encouraging financial organizations to cooperate with such enterprises, creating optimal mechanisms for effective targeted use of financial and investment resources. Considerable attention should be paid to improving the lending system of economic entities in the field of organic production through microcredit, with the involvement of banking and other financial institutions. The measures of the Program in this direction should provide for the provision of financial support on a competitive basis to economic entities in the field of organic production to partially compensate for their costs for certification and purchase of seed material; providing financial support to economic entities in the field of organic production at the expense of own credit resources of banks and other financial institutions as a result of the intensification of their work on microcredit programs; financial support of economic entities in the field of organic production at the expense of resources involved in the form of international assistance and grant programs.

Export credit agencies (hereinafter - ECA) are one of the main players in the market for organic exports crediting [5].

It should be noted that most ECAs do not provide credits under the scheme of international financial organizations (target credit for the company and at the same time for a group of local financial institutions), but act as intermediaries between governments and exporters to provide export financing. Conventionally, all ECAs can be divided into two groups:

- those that can provide financing and ESAs that provide insurance policies and guarantees under which foreign banks credit. The first group includes, for example, US EX-IM Bank (USA) and JBIC (Japan);

- the second group includes almost all European and Asian ECAs.

According to world experience, ECA uses two funding schemes:

1) the borrower is the importing bank under the guarantee of ECA for further financing of the target contract of the importer for the purchase of goods;

2) the borrower is directly the importer - a foreign crediting bank provides a direct credit under the guarantee of ECA.

All ECAs are guided in their activities by the Agreement (the so-called Consensus) on the basic principles of granting official export credits to OECD member countries, as well as the Berne Union agreements. The consensus provides specific and specific rules for project financing. The usual rules include requirements for the number of advance payments of the importer at the level of $15 \%$ of the transaction value; maximum maturities by groups of countries (OECD countries from 5 to 8.5 years, other countries from 5 to 10 years); the order of repayment of the principal amount of debt and accrued interest, crediting of local expenses (maximum 23\% of the order value), minimum interest rates (CIRR) and others. As a rule, most ECAs adhere to the standard terms of debt repayment depending on the amount of the contract price. Under the conditions of participation in the project financing, ECA puts forward the following special requirements for repayment of the borrower's debt:

- the debt repayment schedule should provide that the total amount of repayment in each half-year should not exceed $25 \%$ of the principal amount of the loan;

- the first repayment of the principal amount of the debt must be made no later than 24 months after the loan (not less than $2 \%$ of the principal amount of the loan), and interest - no later than six months;

- interest must be paid annually;

- the credit repayment period should not exceed 7 years and 3 months.

In recent years, most ECAs have been involved in project financing by providing long-term insurance coverage for export operations.

Today, Ukrainian organic production cooperates with a number of international export credit agencies, including ECGD (UK), Euler Hermes (Germany), Atradius (Netherlands), Coface (France), EGAP (Czech 
Republic), MEHIB (Hungary), GIEK (Norway). ), KUKE (Poland), EKF (Denmark), ONDD (Belgium), Finnvera (Finland), OeKB (Austria), SACE (Italy), SERV (Switzerland), EKN (Sweden), Slovak EXIM (Slovakia), EDC ( Canada), US EX-IM (USA), SINOSURE (China), K-sure (Korea), EGFI (Iran) and others.

Unfortunately, no similar ECA has been established in Ukraine: repeated attempts to submit draft laws on the establishment of a separate ECA have not been reflected in the approved legal act.

Ukreximbank is the leader of the trade finance market in Ukraine, as it is easier for government agencies to get support from foreign partners. At the same time, a large share of the trade finance market falls on subsidiaries - Credit Agricole, Citibank, ING Bank, UkrSibbank, OTP Bank, Raiffeisen Bank Aval, Ukrsotsbank [6].

In the foreign market, the main players in trade finance are Deutsche Bank, Commerzbank, UBS Investment Bank, HSBC Bank. Information on the scope of activities of international export agencies is not consolidated and is not officially tracked, so the main projects of Ukrainian organic production with the participation of ECA are collected from the official reports of ECA. The main creditors were international banks: Landesbank Berlin AG (Germany), Credit Suisse AG (France), Rabobank Group (Netherlands), ING Bank International (USA), and others [6].

Ukraine's position on the international market remains the main barrier to the development of cooperation between ECA and Ukrainian organic industries. According to the annual risk assessment conducted by the Organization for Economic Cooperation and Development (OECD) in Europe, Ukraine is in the lowest - seventh - position, which leads to a significant increase in trade agreements between Ukrainian and foreign trading companies due to high premiums.

Further development of organic production requires the development of appropriate credit programs, providing tax benefits for the development of the organic market, and stimulating all its operators.

Conclusions. Organic production is a manufacturing system that supports the health of soils, ecosystems, and people. Depends on environmental processes, biodiversity, and natural cycles specific to local conditions, avoiding the use of non-renewable resources. Organic production combines tradition, innovation, and science to improve the environment and develop fair relationships and a decent standard of living.

As of today, the development of organic production in Ukraine is ensured by exports, as the domestic market is not sufficiently developed. One of the reasons for the stable development of organic products exports is the imbalance of supply and demand for organic products in the European Union, America, and Canada. Appropriate conditions are needed to ensure sustainable development. The key condition is stable export financing.

One of the powerful tools for export financing is crediting. In Ukraine, for organic products export crediting is developed is developing by international export credit agencies.

For the further development of the export of organic products crediting for in Ukraine, it is necessary to develop appropriate credit programs, provide tax benefits for the growth of the organic market, and stimulate all its participates.

\section{Джерела та література}

1. Про органічне виробництво та обіг органічної сільськогосподарської продукції та сировини: Закон України. URL: http://zakon5.rada.gov.ua/laws/show/425-18 (дата звернення: 25.06.2020).

2. Милованов Є.В. Органічне сільське господарство: перспективи для України. Посібник українського хлібороба за 2009 р.: наук.-практ. зб. Ін-ту рослинництва ім. В.Я. Юр’єва. Харків, 2009. 257 с.

3. Ходаковська О. В. Экологизация аграрного производства: современные вызовы и перспективы развития. Экономика АПК. 2015. №5. С. 43.

4. Лупенко Ю. О. Формування попиту та пропозиції на ринку органічної продукції. URL: http://ir.znau.edu.ua/jspui/bitstream/123456789/689/1/Organic_20132_3-9.pdf (дата звернення: 14.04.2020).

5. Бойко С.О. Експортне кредитне агентство як складова державного управління в підвищенні експорту. Національне господарство України: теорія та практика управління: зб. наук. праць. К.: Рада по вивченню продуктивних сил України НАН України, 2010. 320 с. 
6. Консалтингова компанія International Business Contacts. URL: https://iib.com.ua/en/ (дата звернення: 08.05.2020).

7. Органічне виробництво в Україні. URL: http://minagro.gov.ua/node/23346. (дата звернення: 29.06.2020).

8. Огляд ринку. Органічна продукція. URL: https://msb.aval.ua/news/?id=26062. (дата звернення: 11.07.2020).

9. Кузьменко О.Б. Органічне землеробство як фактор євроінтеграції України. Вісник Полтавської державної аграрної академії. 2013. № 3. С. 151-155.

\section{References}

1. Pro orhanichne vyrobnytstvo ta obih orhanichnoi silskohospodarskoi produktsii ta syrovyny: Zakon Ukrainy. [On organic production and circulation of organic agricultural products and raw materials]. (2013). Retrieved from: http://zakon5.rada.gov.ua/laws/show/425-18 [in Ukrainian].

2. Mylovanov Ye.V. (2009) Orhanichne silske hospodarstvo: perspektyvy dlia Ukrainy. [Organic agriculture: prospects for Ukraine]. Posibnyk ukrainskoho khliboroba za 2009 r.: nauk.-prakt. zb. In-tu roslynnytstva im. V.Ia. Yurieva. Kharkiv, 257 [in Ukrainian].

3. Khodakovska O. V. (2015) Эkolohyzatsyia ahrarnoho proyzvodstva: sovremennые vыzovы у perspektyvы razvytyia. [Greening of agricultural production: modern challenges and development prospects.]. Эkonomyka APK Economics of agro-industrial complex, 5, 43 [in Ukrainian].

4. Lupenko Yu. O. (2013) Formuvannia popytu ta propozytsii na rynku orhanichnoi produktsii. [Formation of supply and demand in the organic products market]. Retrieved from: http://ir.znau.edu.ua/jspui/bitstream/123456789/689/1/Organic_20132_3-9.pdf [in Ukrainian].

5. Boiko Ye.O. (2010) Eksportne kredytne ahentstvo yak skladova derzhavnoho upravlinnia v pidvyshchenni eksportu. [Export credit agency as a component of public administration in increasing exports.]. Natsionalne hospodarstvo Ukrainy: teoriia ta praktyka upravlinnia: zb. nauk. prats. National economy of Ukraine: theory and practice of management. K.: Rada po vyvchenniu produktyvnykh syl Ukrainy NAN Ukrainy, 320 [in Ukrainian].

6. Konsaltynhova kompaniia International Business Contacts. [Consulting company of International Business Contacts]. (2019). Retrieved from: https://iib.com.ua/en/ [in Ukrainian].

7. Orhanichne vyrobnytstvo v Ukraini. [Organic production in Ukraine]. (2019). Retrieved from: http://minagro.gov.ua/node/23346 [in Ukrainian].

8. Ohliad rynku. Orhanichna produktsiia. [Market overview. Organic products]. (2019). Retrieved from: https://msb.aval.ua/news/?id=26062. [in Ukrainian].

9. Kuzmenko O.B. (2013) Orhanichne zemlerobstvo yak faktor yevrointehratsii Ukrainy. [Organic farming as a factor of Ukraine's European integration]. Visnyk Poltavskoi derzhavnoi ahrarnoi akademii - Bulletin of the Poltava State Agrarian Academy, 3, 151-155 [in Ukrainian].

Стаття надійшла до редакції 12.08.2020 p. 